\title{
The maladaptive vascular response in COVID-19 acute respiratory distress
}

\section{syndrome and recovery}

David R. Price ${ }^{1,2 \#}$, Elisa Benedetti ${ }^{3 \#}$, Katherine L. Hoffman ${ }^{4}$, Luis Gomez-Escobar ${ }^{1}$,

5 Sergio Alvarez-Mulett ${ }^{1}$, Allyson Capili ${ }^{1}$, Hina Sarwath ${ }^{5}$, Christopher N. Parkhurst ${ }^{1,2}$, Elyse

10 Krumsiek $^{3 *}$, Augustine M.K. Choi ${ }^{1,2^{*}}$

12 " Shared first authorship

$13 *$ Corresponding authors

1. Department of Medicine, Division of Pulmonary and Critical Care Medicine, New YorkPresbyterian Hospital - Weill Cornell Medical Center, Weill Cornell Medicine, New York,

2. Department of Medicine, New York-Presbyterian Hospital - Weill Cornell Medical Center, New York, NY, USA

3. Institute of Computational Biomedicine, Department of Physiology and Biophysics, Weill

$$
\text { Cornell Medicine, New York, NY, USA }
$$

4. Division of Biostatistics, Department of Population Health Sciences, Weill Cornell Medicine, 
medRxiv preprint doi: https://doi.org/10.1101/2021.05.20.21257542; this version posted May 24, 2021. The copyright holder for this preprint (which was not certified by peer review) is the author/funder, who has granted medRxiv a license to display the preprint in perpetuity.

It is made available under a CC-BY-NC-ND 4.0 International license .

24 5. Proteomics Core, Weill Cornell Medicine-Qatar, Qatar Foundation-Education City, Doha,

25 Qatar

26 6. Laboratory of Epigenetics and Immunity, Department of Pathology and Laboratory

27 Medicine, Weill Cornell Medicine, New York, NY, USA

28 7. Department of Medicine, Division of Hematology and Medical Oncology, Weill Cornell

29 Medicine, New York, New York

30 8. Department of Medicine, Division of Nephrology and Hypertension, Weill Cornell Medicine,

$31 \quad$ New York, NY, USA

32 9. Ansary Stem Cell Institute, Division of Regenerative Medicine, Department of

33 Medicine, Weill Cornell Medicine, New York, NY, USA

34 10. Department of Pathology and Laboratory Medicine, New York Presbyterian - Weill Cornell

35 Medicine, New York, NY, USA

36

37 Corresponding Authors:

38 Jan Krumsiek

391305 York Avenue

40 New York, NY 10021

41 Phone: (646) 962-4152

42 Email: jak2043@med.cornell.edu
43 Augustin M.K. Choi

441300 York Avenue

45 New York, NY 10021

46 Phone: (212) 746-4720

47 Email: amc2056@med.cornell.edu

\section{Conflict of Interest Statement}

50 AMKC is a cofounder, stock holder and serves on the Scientific Advisory Board for Proterris,

51 which develops therapeutic uses for carbon monoxide. AMKC also has a use patent on $\mathrm{CO}$. The 
medRxiv preprint doi: https://doi.org/10.1101/2021.05.20.21257542; this version posted May 24, 2021. The copyright holder for this preprint (which was not certified by peer review) is the author/funder, who has granted medRxiv a license to display the preprint in perpetuity.

It is made available under a CC-BY-NC-ND 4.0 International license .

52 spouse of MEC is a cofounder and shareholder, and serves on the Scientific Advisory Board of

53 Proterris, Inc. All other authors declare no competing interests. 
medRxiv preprint doi: https://doi.org/10.1101/2021.05.20.21257542; this version posted May 24, 2021. The copyright holder for this preprint (which was not certified by peer review) is the author/funder, who has granted medRxiv a license to display the preprint in perpetuity.

It is made available under a CC-BY-NC-ND 4.0 International license .

\section{ABSTRACT}

55 Vascular injury is a menacing element of acute respiratory distress syndrome (ARDS)

56 pathogenesis. To better understand the role of vascular injury in COVID-19 ARDS, we used lung

57 autopsy immunohistochemistry and blood proteomics from COVID-19 subjects at distinct

58 timepoints in disease pathogenesis, including a hospitalized cohort at risk of ARDS development

59 ("at risk", $\mathrm{N}=59$ ), an intensive care unit cohort with ARDS ("ARDS", N=31), and a cohort

60 recovering from ARDS ("recovery", N=12). COVID-19 ARDS lung autopsy tissue revealed an

61 association between vascular injury and platelet-rich microthrombi. This link guided the derivation

62 of a protein signature in the at risk cohort characterized by lower expression of vascular proteins

63 in subjects who died, an early signal of vascular limitation termed the maladaptive vascular

64 response. These findings were replicated in COVID-19 ARDS subjects, as well as when bacterial

65 and influenza ARDS patients $(\mathrm{N}=29)$ were considered, hinting at a common final pathway of

66 vascular injury that is more disease (ARDS) then cause (COVID-19) specific, and may be related

67 to vascular cell death. Among recovery subjects, our vascular signature identified patients with

68 good functional recovery one year later. This vascular injury signature could be used to identify

69 ARDS patients most likely to benefit from vascular targeted therapies. 
medRxiv preprint doi: https://doi.org/10.1101/2021.05.20.21257542; this version posted May 24, 2021. The copyright holder for this preprint (which was not certified by peer review) is the author/funder, who has granted medRxiv a license to display the preprint in perpetuity.

It is made available under a CC-BY-NC-ND 4.0 International license .

\section{INTRODUCTION}

Vascular injury has been linked to COVID-19 acute respiratory distress syndrome (ARDS)

$74(1,2)$, including the vascular complications of inflammation and thrombosis. Consistent with this,

75 COVID-19 induced injury to the vascular compartment has been associated with complement

76 activation and micro-thrombosis (3-5), systemic thrombosis $(4,6)$, and to dysregulated immune

77 responses (7-9). However, this focus on inflammation and thrombosis limits our insights into other

78 disruptions associated with aberrant vascular activation. In mice, endothelial overexpression of the

79 angiocrine factor angiopoietin-2 (ANGPT2) induces vascular leakage and disrupts capillary-

80 associated endothelial/pericyte interactions (10). These vascular alterations are countered by

81 ANGPT2 neutralizing antibodies or platelet derived pericyte chemokines such as angiopoietin-1

82 (ANGPT1) and platelet derived growth factor B (PDGFB), demonstrating the homeostatic

83 potential of circulating vascular proteins (10). This is phenocopied in humans where an elevated

84 plasma ANGPT2 to ANGPT1 ratio has been linked to acute lung injury mortality (11). In the right

85 context, ANGPT2 can also disrupt vascular angiogenesis and shorten vascular cell survival,

86 specifically when vascular growth factors are limited (12). More precise understanding of

87 ANGPT2 associated vascular disruptions in COVID-19 ARDS and ARDS generally may inform

88 the timing and patient selection for targeted vascular therapies in ARDS going forward.

89 Heterogeneity in the vascular response to injury between patients may also be associated

90 with COVID-19 ARDS outcomes. Vascular biomarkers have been linked to COVID-19 ARDS

91 severity, including ANGPT2 (13) and vascular cell death is an increasingly recognized

92 consequence of ARDS inflammatory signaling (2, 14-16). Caspase-mediated apoptotic

93 endothelial cell death has been demonstrated in COVID-19 ARDS autopsies (2). However, the

94 clinical significance of circulating vascular and cell death proteins, including their link to COVID- 
medRxiv preprint doi: https://doi.org/10.1101/2021.05.20.21257542; this version posted May 24, 2021. The copyright holder for this preprint (which was not certified by peer review) is the author/funder, who has granted medRxiv a license to display the preprint in perpetuity.

It is made available under a CC-BY-NC-ND 4.0 International license .

9519 ARDS disease and recovery, remains unclear. We hypothesized that differences in circulating

96 vascular proteins are associated with ANGPT2 and could have predictive ability throughout the

97 natural history of COVID-19 ARDS. To test this hypothesis, we quantified vascular proteins first

98 in lung tissue of COVID-19 autopsy patients and then in blood of COVID-19 subjects from distinct

99 disease timepoints (early hospitalization, intensive care, and recovery) and linked this vascular

100 injury signature to relevant clinical outcomes, including mortality. 
medRxiv preprint doi: https://doi.org/10.1101/2021.05.20.21257542; this version posted May 24, 2021. The copyright holder for this preprint (which was not certified by peer review) is the author/funder, who has granted medRxiv a license to display the preprint in perpetuity.

It is made available under a CC-BY-NC-ND 4.0 International license .

\section{RESULTS}

Study cohorts represent COVID-19 ARDS from distinct disease timepoints. An autopsy cohort of 20 COVID-19 subjects was first used to evaluate vascular proteins in human lung tissue. We then analyzed blood vascular proteins in three COVID-19 cohorts at distinct disease timepoints: in early hospitalization before ARDS onset (at risk cohort), after ARDS onset (ARDS cohort), and after discharge from the intensive care unit (recovery cohort). A graphical description of the COVID-19 subjects, including blood sampling, intubation time, and death is shown in Figure 1. Baseline characteristics of these subjects are listed in Supplementary Table 1.

The at risk cohort included 59 COVID-19 subjects admitted to the medical floors of New York Presbyterian Weill Cornell Medical Center (WCM) that did not meet ARDS criteria at study enrollment. The median age of the at risk cohort was 69 years old and was majority male (64\% male versus $36 \%$ female). Fifty-three percent of the cohort had hypertension and $15 \%$ had cancer. The ARDS cohort included 31 COVID-19 ARDS subjects and 29 historic non-COVID-19 ARDS controls admitted to intensive care units (ICUs) at WCM. There were no significant age, sex or race differences between COVID-19 ARDS (N=31) and non-COVID-19 ARDS subjects $(\mathrm{N}=29)$ in the cohort. Cancer was over-represented in the non-COVID-19 ARDS cohort (48.0\% versus $3.2 \%$ in COVID-19 ARDS). There were also notable differences in respiratory physiology. COVID-19 ARDS was associated with more severe hypoxemia (PaO2:FiO2 ratio, P:F ratio 84 versus 193 in non-COVID-19 ARDS) but lower ventilator ratio (1.65 vs 2.89 in non-COVID-19 ARDS). 
medRxiv preprint doi: https://doi.org/10.1101/2021.05.20.21257542; this version posted May 24, 2021. The copyright holder for this preprint (which was not certified by peer review) is the author/funder, who has granted medRxiv a license to display the preprint in perpetuity.

It is made available under a CC-BY-NC-ND 4.0 International license .

The recovery cohort included 12 COVID-19 ARDS subjects with plasma available from

123 both their ICU and recovery time point to allow for longitudinal analysis. The median age of this

124 cohort was 47 years old and was majority male (67\% versus $33 \%$ female).

Angiopoietin 2 is associated with CD61 staining microthrombi in COVID-19 ARDS

subjects. Twenty COVID-19 ARDS lung autopsy specimens were stained for ANGPT2 and CD61

127 protein. High ANGPT2 protein was associated with increased CD61 $(\mathrm{P}=0.005$, Supplementary

128 Figure 1). Representative sections from a high and low ANGPT2 subject are shown in Figure 2.

129 ANGPT2 staining was pronounced in the microvasculature and was mirrored by CD61 positive

130 microthrombi in a similar distribution, linking vascular injury and platelet-rich microvascular

131 microthrombi in COVID-19 ARDS.

The hospitalized at risk cohort blood proteome identifies a maladaptive vascular

134 injury signal seen in the COVID-19 ARDS autopsy specimens, we performed targeted blood 135 proteomics in the at risk cohort. Building on the link between vascular injury and platelet-rich

136 microthrombi in the autopsy analysis, we defined a protein set based on the association of

137 circulating proteins with death and platelet levels (Figure 3A, see Methods for details on the

138 statistical analysis). We included proteins that significantly associated with both parameters (FDR

139 0.1): PDGFA, PDGFB, ANGPT1, SORT1, HBEGF, LAP TGFB1, CD84, CXCL5, MMP9, PAI,

140 IL7, IL1RA, and CXCL1. In addition, we selected 9 proteins that were associated with either death

141 or platelet count (FDR 0.1) and have known vascular functions: ADAMTS13, CD40LG, EGFR,

142 SELP, UPA, VEGFA, GP6, and HO1. TIE2 was additionally included since it is the receptor for

143 ANGPT2 (17). The final set comprised 22 proteins (see Methods and Supplementary Figure 2),

144 including proteins related to vascular junctional integrity (ANGPT1, TIE2), angiogenesis 
medRxiv preprint doi: https://doi.org/10.1101/2021.05.20.21257542; this version posted May 24, 2021. The copyright holder for this preprint (which was not certified by peer review) is the author/funder, who has granted medRxiv a license to display the preprint in perpetuity.

It is made available under a CC-BY-NC-ND 4.0 International license .

145 (PDGFA, PDGFB), platelet degranulation (CD40LG, GP6), and coagulopathy (ADAMTS13, 146 PAI), highlighting the potential functional significance of the identified proteins. Notably, these

147 representative vascular proteins had lower expression in at risk subjects who died (Figure 3B),

148 representing an early signal of vascular limitation in COVID-19 pathogenesis that we termed the

149 maladaptive vascular response.

$150 \quad$ Patient clustering based on this protein set identified three distinct patient groups (clusters

151 A, B, and C in Figure 3C), with mortality and low platelets progressively enriched. Interestingly,

152 this mortality and low platelet enrichment was associated with lower mean abundance of the 22

153 proteins $(\mathrm{P}<0.001$, Supplementary Figure 3A $)$ and higher age $(\mathrm{P}=0.016$, Supplementary Figure

154 3B). Three of the 20 autopsy subjects were also profiled in this cohort (Figure 2 and Figure $3 C$,

155 marked P1, P2, P3). Autopsy patient P1 (high ANGPT2, high CD61) appears in the lowest protein

156 abundance group (cluster C) while autopsy patient P3 (low ANGPT2, low CD61) can be found in

157 the highest protein abundance group (cluster A), linking ANGPT2 mediated lung vascular injury

158 and CD61 microthrombi to low circulating mean vascular protein abundance.

Loss of circulating vascular proteins is associated with low platelets, mortality, and

160 plasma ANGPT2 in ARDS. We next tested our set of 22 proteins in the $A R D S$ cohort. First, we

161 investigated the vascular protein set in COVID-19 ARDS subjects (Supplementary Figure 4A).

162 Confirming the protein results from the COVID-19 at risk cohort, low mean protein abundance of

163 the protein set was associated with worse survival $(\mathrm{P}=0.026$, Supplementary Figure 4B $)$, low

164 platelet count $(\mathrm{P}<0.001$, Supplementary Figure 4C), and older patient age $(\mathrm{P}=0.035$,

165 Supplementary Figure 4D). The addition of non-COVID-19 ARDS patients (bacterial sepsis and

166 influenza ARDS), lead to a similar trend (Figure 4A) with survival $(\mathrm{P}=0.020$, Figure 4B) and low

167 platelets $(\mathrm{P}<0.001$, Supplementary Figure 5A) associated with low mean vascular protein 
medRxiv preprint doi: https://doi.org/10.1101/2021.05.20.21257542; this version posted May 24, 2021. The copyright holder for this preprint (which was not certified by peer review) is the author/funder, who has granted medRxiv a license to display the preprint in perpetuity.

It is made available under a CC-BY-NC-ND 4.0 International license .

168 abundance $(\mathrm{P}<0.001$, Supplementary Figure 5B). Notably, plasma ANGPT2 was higher in the

169 low mean protein abundance cluster $(\mathrm{P}=0.001$, Figure $4 \mathrm{C}$ and Supplementary Figure 4E),

170 linking low vascular protein abundance and plasma ANGPT2 in diverse ARDS subjects.

Interestingly, when COVID-19 ARDS was considered alone (Supplementary Figure 4),

172 this higher vascular injury signature was present in 39\% (12 of 31) of COVID-19 ARDS subjects,

173 yet when all three infection types were considered (Figure 4), only 13\% (4 of 31) of COVID-19

174 ARDS were in the higher vascular injury cluster compared to 58\% (14 of 24) of bacterial sepsis

175 ARDS and 80\% (3 of 4) of influenza ARDS subjects, demonstrating that vascular injury may be

176 relative to the causative infection, with COVID-19 ARDS overall being associated with less

177 vascular injury than bacterial sepsis and influenza related ARDS. This finding is supported by a

178 lower ventilator ratio in COVID-19 ARDS subjects compared to non-COVID-19 (Supplementary

179 Table 1) a physiologic surrogate for vascular injury in ARDS (18). This is also consistent with

180 previous investigations showing higher platelet counts and less platelet consumption in COVID-

18119 compared to bacterial sepsis ARDS (19).

Induction of vascular cell death is associated with ARDS vascular injury. Having

183 validated our vascular injury signature in diverse ARDS populations, we assessed whether ARDS

184 vascular injury could be associated with genetically regulated necrotic cell death, known as

185 necroptosis. We first demonstrated increased expression of plasma RIPK3, a vital necroptosis

186 protein (20), in ARDS subjects with higher vascular injury ( $\mathrm{P}=0.020$, Figure 5A). Plasma RIPK3

187 was also correlated with plasma ANGPT2 $(r=0.40, P=0.003$, Figure 5B), supporting the existence

188 of a link between circulating necroptosis proteins and ARDS-related vascular injury. COVID-19

189 ARDS autopsy subjects demonstrated diffuse microvascular staining for pMLKL, a terminal

190 protein in necrotic cell death execution downstream of RIPK3 (Figure 5C), including the high 
medRxiv preprint doi: https://doi.org/10.1101/2021.05.20.21257542; this version posted May 24, 2021. The copyright holder for this preprint (which was not certified by peer review) is the author/funder, who has granted medRxiv a license to display the preprint in perpetuity.

It is made available under a CC-BY-NC-ND 4.0 International license .

191 vascular injury autopsy subject P1 (see label P1 in Figure 2, Figure 3, and Figure 5), linking 192 induction of necroptosis mediator pMLKL to lung vascular injury and low circulating vascular

193 protein abundance in COVID-19 ARDS.

194 Among COVID-19 ARDS recovery subjects, longitudinal plasma proteomics

195 identifies a stable protein trajectory associated with good functional recovery. We further

196 investigated whether our 22 protein set had predictive ability during recovery. Patient clustering

197 based on the recovery plasma protein set revealed two distinct clusters (Figure 6A). Again, the

198 low protein abundance cluster was associated with platelet level $(\mathrm{P}=0.049$, Supplementary

199 Figure 6A) and higher age $(\mathrm{P}=0.049$, Supplementary Figure 6B). One year follow up functional

200 recovery data based on the EQ-5D-3L questionnaire was available on 11 of these 12 recovery

201 individuals (top annotation in Figure 6A, see Methods for details). Notably, the cluster of patients

202 with lower abundance of our protein set $(\mathrm{P}=0.004$, Supplementary Figure 6C) displayed worse

203 functional recovery 12 months after admission from the ICU, while higher vascular protein

204 abundance was associated with better functional recovery $(\mathrm{P}=0.027$, Figure $6 \mathbf{B})$. In order to test

205 whether the protein trajectory from ICU to recovery was different between good and poor

206 functional recovery subjects, we compared the differences in protein abundances between the two

207 timepoints in the two patient clusters (see Methods). For proteins representative of junctional

208 barrier integrity (TIE2, Padj=0.20), angiogenesis (PDGFA, Padj=0.20), platelet degranulation

209 (GP6, Padj=0.20), and coagulopathy (PAI, Padj=0.20), good functional recovery was associated

210 with stable protein trajectory (Figure 6C), as opposed to the large protein changes among the poor

211 recovery subjects. This stable trajectory among good functional recovery subjects was similar for

212 platelet levels $(\mathrm{P}=0.086$, Supplementary Figure 6E) and ANGPT2 $(\mathrm{p}=0.083$, Supplementary

213 Figure 6F). 
medRxiv preprint doi: https://doi.org/10.1101/2021.05.20.21257542; this version posted May 24, 2021. The copyright holder for this preprint (which was not certified by peer review) is the author/funder, who has granted medRxiv a license to display the preprint in perpetuity.

It is made available under a CC-BY-NC-ND 4.0 International license.

\section{DISCUSSION}

215 In this study, we traced a maladaptive vascular response through the natural history of

216 COVID-19 ARDS from hospital admission to either recovery or death. Reflected in both the lung

217 tissue and blood proteome, we demonstrated the clinical relevance of the low abundance of

218 circulating vascular proteins with known vascular functions and implied a link with vascular cell

219 death, and in particular specialized necroptotic cell death.

220 This vascular phenotype is notably present in certain COVID-19 subjects prior to ICU

221 admission. While vascular injury spans the COVID-19 disease continuum from asymptomatic blue

222 toes to catastrophic thromboembolic disease and ARDS-associated microangiopathy, our

223 identification of broad loss of vascular signaling in early severe disease generalizes this

224 maladaptive vascular response to the large population of hospitalized COVID-19 subjects. The

225 loss of vascular proteins could result from SARS-CoV-2 endothelial infection $(1,2)$, although this

226 remains controversial and thus far only reproducible in artificially engineered endothelial cell (21),

227 while primary human endothelial cell appear resistant to infection (22). Alternatively, in common

228 with bacterial sepsis $(16,23,24)$ and influenza infection (25), unrestrained COVID-19 related

229 inflammatory signaling (9) could similarly induce vascular cell death. Indeed, we demonstrate

230 induction of genetically regulated necrotic cell death mediator (pMLKL) in the microvasculature

231 of high vascular injury COVID-19 autopsy subjects. Diverse upstream mediators previously linked

232 to COVID-19 (e.g. TNF-alpha (26), interferons (27-31)) can induce necroptosis (20), providing a

233 crucial link between SARS-CoV-2 infection and both direct (virus) or indirect (TNF, interferons)

234 induction of vascular cell death in COVID-19 subjects.

235 The role of activated platelets in vascular injury and repair is also apparent in our data.

236 Activated platelets amplify immune responses in early ARDS but also play an essential role in 
medRxiv preprint doi: https://doi.org/10.1101/2021.05.20.21257542; this version posted May 24, 2021. The copyright holder for this preprint (which was not certified by peer review) is the author/funder, who has granted medRxiv a license to display the preprint in perpetuity. It is made available under a CC-BY-NC-ND 4.0 International license .

237 vascular repair. The consistently low platelet levels across our cohorts and the extensive 238 microthrombi observed in our autopsy subjects implies a circulating milieu of platelet 239 consumption. This milieu of platelet consumption is supported by a blood signature of ongoing 240 thrombolysis (high UPA and low PAI) and low levels of platelet derived proteins (low SELP, and 241 GP6) in our high vascular injury subjects. Relative loss of ADAMTS13, linked to secondary 242 microangiopathy in COVID-19 (32), is similarly deficient in our higher vascular injury subjects, 243 linking platelet consumption with microangiopathy in severe COVID-19. Low platelets have 244 previously been linked to ARDS mortality (33) and our data suggest this may be related to 245 depletion in platelet related angiogenic (34-36) and junctional barrier factors (37-40). 246 Consistently low circulating angiogenic (low PDGFA and PDGFB) and barrier protein (low 247 ANGPT1) in our higher vascular injury and low platelet subjects imply limitations in these 248 essential reparative processes.

The validation of our vascular phenotype across diverse causes of ARDS broadens the 250 relevance of our findings. In linking low platelets, vascular function, and mortality in COVID-19, 251 bacterial sepsis, and influenza ARDS, we hint at a common final pathway of vascular injury that 252 is more disease- (ARDS) than cause- (COVID-19) specific. Of note is that this vascular injury 253 pattern may be related to a reduced baseline vascular resilience in our high vascular injury subjects. 254 Consistently, our high vascular injury subjects are older (41), have worse baseline renal function 255 (42, 43), and are more likely to have cancer (44) (Supplementary Table 2), all variables know to 256 be associated with vascular disease. 
medRxiv preprint doi: https://doi.org/10.1101/2021.05.20.21257542; this version posted May 24, 2021. The copyright holder for this preprint (which was not certified by peer review) is the author/funder, who has granted medRxiv a license to display the preprint in perpetuity.

It is made available under a CC-BY-NC-ND 4.0 International license .

260 human experimental therapies, including ANGPT1 supplementation trial currently underway in

261 COVID-19 subjects (49). And while a ANGPT2 neutralizing antibody study in hospitalized patient

262 with COVID-19 was stopped for futility in October 2020 (50), our data could improve patient

263 selection for similar trials in the future, including the use of platelet levels to identify subjects with

264 vascular limitation.

265 Finally, our identification of a vascular recovery proteome is novel. An estimated 2 million

266 patients have been hospitalized in the United States since the start of the COVID-19 pandemic,

267 with the overwhelming majority recovering (51). But even in recovery, patients remain at risk for

268 disease related morbidity and mortality (52). We demonstrate that a stable circulating vascular

269 proteome is important for functional recovery. This association between vascular stability, platelet

270 levels, and functional recovery could also support platelet levels as a novel biomarker in ARDS

271 recovery. Larger studies will be needed to validate this observation.

272 In summary, we identify an early vascular injury signal in COVID-19 ARDS that has

273 predictive value in early disease through to recovery and well as in bacterial sepsis and influenza

274 ARDS and could improve patient selection and timing of vascular targeted therapies in ARDS. 
medRxiv preprint doi: https://doi.org/10.1101/2021.05.20.21257542; this version posted May 24, 2021. The copyright holder for this preprint (which was not certified by peer review) is the author/funder, who has granted medRxiv a license to display the preprint in perpetuity.

It is made available under a CC-BY-NC-ND 4.0 International license .

\section{METHODS}

\section{Study design}

This study enrolled COVID-19 subjects at New York Presbyterian Weill Cornell Medical 278 Center (WCM) between March 15 and August 17, 2020 with blood specimens obtained during

279 routine care and as part of existing study protocols. Additional historic non-COVID-19 ARDS

280 samples from influenza and bacterial ARDS patients prospectively enrolled into the Weill Cornell

281 Biobank of Critical Illness (BOCI) from October 20, 2014 until May 24, 2020 were included as

282 part of the ARDS cohort. COVID-19 study samples were analyzed according to ARDS status (at 283 risk, ARDS or recovery) at study enrollment. The at risk cohort included 59 adult (>18) non-

284 pregnant COVID-19 subjects admitted to the general wards of WCM with serum available and 285 who did not meet ARDS criteria at study enrollment. The ARDS cohort included adult (>18) non286 pregnant COVID-19 $(\mathrm{N}=31)$ and historic non-COVID ARDS $(\mathrm{N}=29)$ subjects admitted to the 287 intensive care unit (ICU) at WCM. For the $A R D S$ cohort, only study subjects meeting ARDS 288 criteria and with blood sampling within 10 days of ICU admission were considered for analysis.

289 The recovery cohort included 12 adult ( $>18)$ non-pregnant COVID-19 ARDS subjects with plasma 290 samples available from both the time of ICU care and the subsequent recovery period to allow for

291 longitudinal analyses. Recovery blood samples were obtained from patients convalescing in the 292 hospital rehabilitation floors, as well as from the New York Presbyterian Weill Cornell Medicine 293 Post-ICU recovery clinic. 
medRxiv preprint doi: https://doi.org/10.1101/2021.05.20.21257542; this version posted May 24, 2021. The copyright holder for this preprint (which was not certified by peer review) is the author/funder, who has granted medRxiv a license to display the preprint in perpetuity.

It is made available under a CC-BY-NC-ND 4.0 International license .

The study was approved by the institutional review board (IRB) at WCM (20-05022072, 20-0302168, 20-03021681, and 1811019771). Written informed consent was received from all

298 participants prior to inclusion in the study.

\section{Blood sampling}

In the at risk cohort, between 1 and 3 consecutive daily samples were obtained from our central lab after routine processing to obtain serum. To obtain serum, blood collected in serum separator tubes (SST) was processed within 2 hours of venipuncture. Whole blood was centrifuged at $1,500 \mathrm{~g}$ for 7 minutes. The serum layer was aliquoted and stored at $-80^{\circ} \mathrm{C}$. These samples were obtained with a waiver of informed consent. In this cohort, samples collected after patient intubation were excluded from the analysis. In the ARDS and recovery cohorts, plasma was

307 isolated from study subjects according to our existing plasma isolation protocol (53-56). To obtain 308 plasma, blood collected in EDTA tubes was processed within 6 hours of venipuncture. Whole 309 blood was centrifuged at $490 \mathrm{~g}$ for 10 minutes. The plasma layer was removed in $200 \mathrm{uL}$ aliquots 310 and stored at -80 .

\section{Clinical evaluation}

314 record (EMR) as described previously $(57,58)$. Baseline comorbidities were manually abstracted

315 from the EMR. Baseline clinical data (labs, severity of illness, ventilator data) were measured at 316 time of blood sampling in both the at risk cohort and $A R D S$ cohort. Severity of illness was defined 317 by the sequential organ failure assessment score (SOFA) (59). ARDS was determined according 318 to the Berlin definition with ARDS severity capped at mild for subjects on non-invasive ventilation 
medRxiv preprint doi: https://doi.org/10.1101/2021.05.20.21257542; this version posted May 24, 2021. The copyright holder for this preprint (which was not certified by peer review) is the author/funder, who has granted medRxiv a license to display the preprint in perpetuity.

It is made available under a CC-BY-NC-ND 4.0 International license .

319 (60). Two critical care investigators independently adjudicated the ARDS diagnosis. In all study 320 subjects, COVID-19 was diagnosed if a subject had a syndrome compatible with COVID-19 and

321 a nasopharangeal (NP) swab positive for SARS-CoV-2 by reverse transcriptase polymerase chain

322 reaction (RT-PCR).

324 Recovery Evaluation

Recovery subjects were assessed for recovery using the EuroQol-5D-3L (EQ-5D-3L)

326 questionnaire (61) at 12 months after ICU admission. The EQ-5D-3L is a self-assessment of the

327 patient recovery, and considers 5 distinct domains, namely mobility, self-care, usual activities,

328 pain or discomfort, and anxiety or depression (62). Each domain was scored 0, 1, or 2 depending

329 on whether the patient reported no, some, or extensive limitations in each respective domain. For

330 each patient, a final score was defined as the sum of the scores across the five domains and treated

331 as an ordinal variable in the statistical analysis. Maximal functional limitation would have a score

332 of $(2 * 5=) 10$ while an optimal recovery would be scored 0 .

334 Autopsy studies

335 Twenty autopsies performed between March 19 and June 30, 2020 with pre-mortem

336 nasopharyngeal swabs positive for SARS-CoV-2 were considered for lung tissue staining. Lung

337 tissue specimens were fixed in 10\% formalin for $48-72$ hours. Hematoxylin and eosin staining

338 were performed for all cases. Immunohistochemistry was carried out for angiopoietin-2 (sc-74403,

339 Santa Cruz, TX, 1:100), CD-61 (CD61 clone 2F2, Leica Biosystems, IL) and phosphorylated

340 mixed lineage kinase domain-like (pMLKL, MAB91871, NOVUS Biologicals, CO, 1:750 with

341 casein for background reduction). Specimens were scanned by whole-slide image technique using 
medRxiv preprint doi: https://doi.org/10.1101/2021.05.20.21257542; this version posted May 24, 2021. The copyright holder for this preprint (which was not certified by peer review) is the author/funder, who has granted medRxiv a license to display the preprint in perpetuity.

It is made available under a CC-BY-NC-ND 4.0 International license .

342 an Aperio slide scanner with a resolution of $0.24 \mu \mathrm{m} /$ pixel. Control tissue was from non-diseased

343 sections of lung taken during clinically indicated lung biopsies. Quantification of ANGPT2 and

344 CD61 was performed on four random 20X images selected using a random overlay of points and

345 excluding fields with large vessels or airway. All twenty autopsies were analyzed using

346 Immunohistochemistry profiler (63) as a plugin for Image J (National Institutes of Health, USA).

347 High, intermediate, low, and overall percent positive was averaged over the four

348 measurements. The median ANGPT2 quantification was used to define the high (>median) and

349 low (<median) ANGPT2 staining. The association between CD61 and ANGPT2 was then

350 calculated based on CD61 quantification in the low and high ANGPT2 groups using Mann-

351 Whitney U test for continuous variables.

\section{O-link Plasma Proteomics}

Plasma and serum samples from the at risk, ARDS and recovery cohorts were profiled using

355 O-Link through the Proteomics Core of Weill Cornell Medicine-Qatar. The O-link assays were 356 performed using Inflammation (v.3021), Cardiovascular II (v.5005), and Cardiovascular III

357 (v.6113) panels (O-link, Uppsala, Sweden). EDTA plasma and serum samples were heat-

358 inactivated at 56 degrees for 15 mins according to the virus inactivation protocol provided by O-

359 link) (64). The protein measurements were performed with the Proximity Extension Assay

360 technology (PEA) according to manufacturer's instructions. In summary, high throughput real-

361 time PCR of reporter DNA linked to protein specific antibodies was performed on a 96-well 362 integrated fluidic circuits chip (Fluidigm, San Francisco, CA). Signal quantification was carried

363 out on a Biomark HD system (Fluidigm, San Francisco, CA). Each sample was spiked with quality

364 controls to monitor the incubation, extension, and detection steps of the assay. Additionally, 
medRxiv preprint doi: https://doi.org/10.1101/2021.05.20.21257542; this version posted May 24, 2021. The copyright holder for this preprint (which was not certified by peer review) is the author/funder, who has granted medRxiv a license to display the preprint in perpetuity.

It is made available under a CC-BY-NC-ND 4.0 International license.

365 samples representing external, negative and inter-plate controls were included in each analysis run.

366 From raw data, real time PCR cycle threshold $(\mathrm{Ct})$ values were extracted using the Fluidigm RT-

367 PCR analysis software at a quality threshold of 0.5 and linear baseline correction. Ct values were

368 further processed using the O-link NPX manager software (O-link, Uppsala, Sweden). Here, log2-

369 transformed Ct values from each sample and analyte were normalized based on spiked-in extension

370 controls and scale-inverted to obtain normalized log2 scaled Protein eXpression (NPX) values.

371 NPX values were further adjusted based on the median of inter plate controls (IPC) for each protein

372 and intensity median scaled between all samples and plates.

373

The at risk cohort was profiled in two separate runs. The second run included a total of 11

374 samples, among which 5 bridge samples were used to scale this batch toward the first one, as

375 recommended by Olink. First, for each bridge sample, the pairwise difference between the first

376 and second batch was computed. An overall batch adjustment factor was then derived as the

377 median of these pairwise differences and subtracted to the values in the second batch.

378 Subsequently, protein levels were exponentiated, normalized using probabilistic quotient

379 normalization (65) and $\log 2$-retransformed. Missing values were imputed using a k-nearest

380 neighbors approach (66) $(\mathrm{k}=10) .10$ proteins were measured across multiple panels and, therefore,

381 their duplicated values were averaged, leaving a total of 266 unique proteins. Protein values were

382 standardized prior to statistical analysis.

383

384 Protein subset derivation

The protein vascular signature was derived in the at risk cohort. First, we associated each

386 of the 266 measured proteins to death and platelet count, respectively. Then, we selected proteins

387 associated with both outcomes (adjusted $\mathrm{p}$-value $=<0.1$, see Statistical Analysis section for details). 
medRxiv preprint doi: https://doi.org/10.1101/2021.05.20.21257542; this version posted May 24, 2021. The copyright holder for this preprint (which was not certified by peer review) is the author/funder, who has granted medRxiv a license to display the preprint in perpetuity.

It is made available under a CC-BY-NC-ND 4.0 International license .

Additionally, we included proteins associated with either mortality or platelet count (adjusted pvalue $=<0.1)$ and with known, well characterized links to vascular function. TIE2 was additionally included as it is the receptor for ANGPT2(17).

\section{ELISA measurements}

Plasma samples from the $A R D S$ and Recovery cohorts were used for enzyme-linked immunosorbent assays (ELISA) according to manufacturer recommendations. Human ANGPT2 (R\&D, CAT\#DANG20) and receptor interacting protein kinase 3 (RIPK3, Cusabio, CAT\#CSBEL019737HU) kits were used to measure plasma protein levels. Plasma samples were diluted (1:8 dilution for ANGPT2, 1:10 for RIPK3) prior to plating. Final sample absorbance was measured at $450 \mathrm{~nm}$ with wavelength correction performed at $570 \mathrm{~nm}$. Sample concentrations were calculated from a four-parameter logistic curve created from known standard concentrations. Dilution factors were accounted for to calculate the final sample concentration. Plasma ANGPT2 and RIPK3 values were $\log 10$-transformed prior to statistical analysis.

\section{Statistics}

In the at risk cohort proteomic analysis, protein associations to death (i.e. whether the

405 patient ended up dying) and platelet count (minimum value across the sampling days) were computed using a mixed linear effect model, which allows to properly account for the multiple

407 samples collected per patient. The model was formulated as follows: protein outcome + replicate + batch $+(1 \mid$ patient $)$, where outcome was either death or platelet count,

409 replicate indicated the day of blood sample draw (first, second or third since hospital admission),

410 and batch indicated whether the sample was measured in the first or second run. Association p- 
medRxiv preprint doi: https://doi.org/10.1101/2021.05.20.21257542; this version posted May 24, 2021. The copyright holder for this preprint (which was not certified by peer review) is the author/funder, who has granted medRxiv a license to display the preprint in perpetuity.

It is made available under a CC-BY-NC-ND 4.0 International license.

411 values were corrected for multiple testing using the Benjamini-Hochberg method for controlling

412 the false discovery rate (67). Adjusted p-values less than 0.1 were considered significant.

413 For all cohorts, patient hierarchical clustering based on the standardized proteomics value

414 was performed using Ward linkage and Euclidean distance. The differential analysis between

415 patient clusters was performed using Mann-Whitney U tests for continuous variables, Kendall's

416 rank correlation for ordinal variables, and log-rank tests for survival times. The correlation

417 between ANGPT2 and RIPK3 was estimated using Pearson correlation. For these analyses, a p-

418 value of less than 0.05 was considered significant.

419 In the recovery cohort, we first divided patients into two groups based on unsupervised

420 hierarchical clustering (Ward linkage, Euclidean distance) performed on the recovery timepoint.

421 Then, for each patient we calculated the protein abundance difference (delta) between the ICU and

422 recovery timepoints. Finally, for each protein we investigated whether the protein delta was

423 different across the two patient groups using the linear model delta $\sim$ group. P-values were

424 corrected for multiple tests using the Benjamini-Hochberg method. Given the small sample size

425 and validation of protein set in two prior cohort, we considered an adjusted p-value less than 0.25

426 as significant.

427 All statistical analyses were performed in $\mathrm{R}$ 4.0.1. The $\mathrm{R}$ code used to generate the

428 statistical findings presented in this paper is publicly available at

429 https://github.com/krumsieklab/covid-vascular-injury.

\section{Data and Code Availability}

The datasets used for this study include sensitive patient information extracted from the 
434 make them publicly available, even after being subjected to deidentification techniques. To request

435 access to the de-identified minimal datasets underlying the findings illustrated in our paper,

436 interested and qualified researchers should contact Information Technologies \& Services

437 Department of Weill Cornell Medicine support@med.cornell.edu.

438 The R Code used to generate all the statistical results presented in this paper is available at

439 https://github.com/krumsieklab/covid-vascular-injury. 
medRxiv preprint doi: https://doi.org/10.1101/2021.05.20.21257542; this version posted May 24, 2021. The copyright holder for this preprint (which was not certified by peer review) is the author/funder, who has granted medRxiv a license to display the preprint in perpetuity.

It is made available under a CC-BY-NC-ND 4.0 International license .

\section{AUTHOR CONTRIBUTIONS}

458 DRP, EB share the first author position. DRP is listed first based on higher total effort to the

459 project. DRP, EB, JK, AMKC designed the study. DRP, ACR, and ACB performed the autopsy

460 staining analyses. LGE, SAM, AC, CNP, AR, JGC, SZJ processed samples and organized the

461 patient clinical data. EB, HS, RB, MB, KC, FS, JK analyzed the proteomic data. KLH and IE

462 provided statistical support for patient clinical data. EL, KW, CNP, LL perform functional

463 assessment of recovery subjects. DRP, EB, JK, AMKC, RB, FS, JGC, EJS, ACR, HOR, JCL,

464 MEC, and SR critically appraised the final dataset. DRP, EB wrote the manuscript. All authors

465 approved the final manuscript.

466

467

468

469

470

471

472

473

474

475

476

477

478

479 
medRxiv preprint doi: https://doi.org/10.1101/2021.05.20.21257542; this version posted May 24, 2021. The copyright holder for this preprint (which was not certified by peer review) is the author/funder, who has granted medRxiv a license to display the preprint in perpetuity.

It is made available under a CC-BY-NC-ND 4.0 International license .

\section{ACKNOWLEDGEMENTS}

481 This work is supported by the Biomedical Research Program at Weill Cornell Medicine in

482 Qatar, a program funded by the Qatar Foundation. JK is supported by the National Institute of

483 Aging of the National Institutes of Health under award 1U19AG063744. The authors thank Ilias

484 I. Siempos for critically reviewing the manuscript.

485

486 
medRxiv preprint doi: https://doi.org/10.1101/2021.05.20.21257542; this version posted May 24, 2021. The copyright holder for this preprint (which was not certified by peer review) is the author/funder, who has granted medRxiv a license to display the preprint in perpetuity.

It is made available under a CC-BY-NC-ND 4.0 International license .

\section{REFERENCES}

1. Ackermann M et al. Pulmonary Vascular Endothelialitis, Thrombosis, and Angiogenesis in Covid-19. N. Engl. J. Med. 2020;383(2):120-128.

2. Varga $Z$ et al. Endothelial cell infection and endotheliitis in COVID-19. Lancet 2020;395(10234):1417-1418.

492 3. Bradley BT et al. Histopathology and ultrastructural findings of fatal COVID-19 infections in 493 Washington State: a case series. Lancet 2020;396(10247):320-332.

494 4. Magro C et al. Complement associated microvascular injury and thrombosis in the 495 pathogenesis of severe COVID-19 infection: A report of five cases. Transl Res 2020;220:1-13.

496 5. Borczuk AC et al. COVID-19 pulmonary pathology: a multi-institutional autopsy cohort from 497 Italy and New York City. Mod. Pathol. 2020;33(11):2156-2168.

498 6. Choi JJ et al. D-dimer cut-off points and risk of venous thromboembolism in adult

499 hospitalized patients with COVID-19. Thromb. Res. 2020;196:318-321.

500 7. Jose RJ, Manuel A. COVID-19 cytokine storm: the interplay between inflammation and 501 coagulation. Lancet Respir. Med. 2020;8(6):e46-e47.

502 8. Mangalmurti N, Hunter CA. Cytokine Storms: Understanding COVID-19. Immunity $503 \quad 2020 ; 53(1): 19-25$.

504 9. Moore JB, June CH. Cytokine release syndrome in severe COVID-19. Science $505 \quad 2020 ; 368(6490): 473-474$.

506 10. Ziegler T et al. Angiopoietin 2 mediates microvascular and hemodynamic alterations in 507 sepsis. J. Clin. Invest. [published online ahead of print: July 1, 2013]; doi:10.1172/JCI66549 508 11. Ong $\mathrm{T}$ et al. Ratio of angiopoietin-2 to angiopoietin-1 as a predictor of mortality in acute 509 lung injury patients. Crit. Care Med. 2010;38(9):1845-1851. 
medRxiv preprint doi: https://doi.org/10.1101/2021.05.20.21257542; this version posted May 24, 2021. The copyright holder for this preprint (which was not certified by peer review) is the author/funder, who has granted medRxiv a license to display the preprint in perpetuity.

It is made available under a CC-BY-NC-ND 4.0 International license .

510 12. Lobov IB, Brooks PC, Lang RA. Angiopoietin-2 displays VEGF-dependent modulation of

511 capillary structure and endothelial cell survival in vivo. Proc. Natl. Acad. Sci. USA

$512 \quad 2002 ; 99(17): 11205-11210$.

513 13. Hultström $\mathrm{M}$ et al. Elevated Angiopoietin-2 inhibits thrombomodulin-mediated

514 anticoagulation in critically ill COVID-19 patients. medRxiv [published online ahead of print:

515 January 15, 2021]; doi:10.1101/2021.01.13.21249429

516 14. Cheng KT et al. Caspase-11-mediated endothelial pyroptosis underlies endotoxemia-induced

517 lung injury. J. Clin. Invest. 2017;127(11):4124-4135.

518 15. Qing DY et al. Red blood cells induce necroptosis of lung endothelial cells and increase

519 susceptibility to lung inflammation. Am. J. Respir. Crit. Care Med. 2014;190(11):1243-1254.

520 16. Zelic M et al. RIP kinase 1-dependent endothelial necroptosis underlies systemic

521 inflammatory response syndrome. J. Clin. Invest. 2018;128(5):2064-2075.

522 17. Kim $\mathrm{M}$ et al. Opposing actions of angiopoietin-2 on Tie2 signaling and FOXO1 activation. $J$.

523 Clin. Invest. 2016;126(9):3511-3525.

524 18. Morales-Quinteros L et al. Estimated dead space fraction and the ventilatory ratio are

525 associated with mortality in early ARDS. Ann. Intensive Care 2019;9(1):128.

526 19. Helms J et al. High risk of thrombosis in patients with severe SARS-CoV-2 infection: a

527 multicenter prospective cohort study. Intensive Care Med. 2020;46(6):1089-1098.

528 20. Choi ME, Price DR, Ryter SW, Choi AMK. Necroptosis: a crucial pathogenic mediator of

529 human disease. JCI Insight 2019;4(15). doi:10.1172/jci.insight.128834

530 21. Monteil V et al. Inhibition of SARS-CoV-2 Infections in Engineered Human Tissues Using

531 Clinical-Grade Soluble Human ACE2. Cell 2020;181(4):905-913.e7. 
medRxiv preprint doi: https://doi.org/10.1101/2021.05.20.21257542; this version posted May 24, 2021. The copyright holder for this preprint (which was not certified by peer review) is the author/funder, who has granted medRxiv a license to display the preprint in perpetuity.

It is made available under a CC-BY-NC-ND 4.0 International license .

532 22. Ahmetaj-Shala B et al. Resistance of endothelial cells to SARS-CoV-2 infection in vitro.

533 BioRxiv [published online ahead of print: November 9, 2020]; doi:10.1101/2020.11.08.372581

534 23. Polykratis A et al. Cutting edge: RIPK1 Kinase inactive mice are viable and protected from

535 TNF-induced necroptosis in vivo. J. Immunol. 2014;193(4):1539-1543.

536 24. Najjar M et al. RIPK1 and RIPK3 Kinases Promote Cell-Death-Independent Inflammation by

537 Toll-like Receptor 4. Immunity 2016;45(1):46-59.

538 25. Shubina $\mathrm{M}$ et al. Necroptosis restricts influenza A virus as a stand-alone cell death

539 mechanism. J. Exp. Med. 2020;217(11). doi:10.1084/jem.20191259

540 26. Del Valle DM et al. An inflammatory cytokine signature predicts COVID-19 severity and

541 survival. Nat. Med. 2020;26(10):1636-1643.

542 27. Hadjadj J et al. Impaired type I interferon activity and inflammatory responses in severe

543 COVID-19 patients. Science 2020;369(6504):718-724.

544 28. Zhang Q et al. Inborn errors of type I IFN immunity in patients with life-threatening COVID-

545 19. Science 2020;370(6515). doi:10.1126/science.abd4570

546 29. Bastard P et al. Autoantibodies against type I IFNs in patients with life-threatening COVID-

547 19. Science 2020;370(6515). doi:10.1126/science.abd4585

548 30. Grajales-Reyes GE, Colonna M. Interferon responses in viral pneumonias. Science

$5492020 ; 369(6504): 626-627$.

550 31. Lee JS et al. Immunophenotyping of COVID-19 and influenza highlights the role of type I

551 interferons in development of severe COVID-19. Sci. Immunol. 2020;5(49).

552 doi:10.1126/sciimmunol.abd1554

553 32. Martinelli $\mathrm{N}$ et al. A relative ADAMTS13 deficiency supports the presence of a secondary

554 microangiopathy in COVID 19. Thromb. Res. 2020;193:170-172. 
medRxiv preprint doi: https://doi.org/10.1101/2021.05.20.21257542; this version posted May 24, 2021. The copyright holder for this preprint (which was not certified by peer review) is the author/funder, who has granted medRxiv a license to display the preprint in perpetuity.

It is made available under a CC-BY-NC-ND 4.0 International license .

555 33. Wang $\mathrm{T}$ et al. Thrombocytopenia is associated with acute respiratory distress syndrome

556 mortality: an international study. PLoS One 2014;9(4):e94124.

557 34. Kisucka $\mathrm{J}$ et al. Platelets and platelet adhesion support angiogenesis while preventing

558 excessive hemorrhage. Proc. Natl. Acad. Sci. USA 2006;103(4):855-860.

559 35. Hall-Glenn F et al. CCN2/connective tissue growth factor is essential for pericyte adhesion

560 and endothelial basement membrane formation during angiogenesis. PLoS One

$561 \quad 2012 ; 7(2): \mathrm{e} 30562$.

562 36. Lakka Klement G, Shai E, Varon D. The role of platelets in angiogenesis. In: Platelets.

563 Elsevier; 2013:487-502

564 37. Li JJ, Huang YQ, Basch R, Karpatkin S. Thrombin induces the release of angiopoietin-1

565 from platelets. Thromb. Haemost. 2001;85(2):204-206.

566 38. Thurston G et al. Angiopoietin-1 protects the adult vasculature against plasma leakage. Nat.

567 Med. 2000;6(4):460-463.

568 39. Nurden AT. Platelets, inflammation and tissue regeneration. Thromb. Haemost. 2011;105

569 Suppl 1:S13-33.

570 40. Hwang B et al. Stimulation of angiogenesis and survival of endothelial cells by human

571 monoclonal Tie2 receptor antibody. Biomaterials 2015;51:119-128.

572 41. Savji N et al. Association between advanced age and vascular disease in different arterial

573 territories: a population database of over 3.6 million subjects. J. Am. Coll. Cardiol.

$574 \quad 2013 ; 61(16): 1736-1743$.

575 42. Anavekar NS et al. Relation between renal dysfunction and cardiovascular outcomes after

576 myocardial infarction. N. Engl. J. Med. 2004;351(13):1285-1295. 
medRxiv preprint doi: https://doi.org/10.1101/2021.05.20.21257542; this version posted May 24, 2021. The copyright holder for this preprint (which was not certified by peer review) is the author/funder, who has granted medRxiv a license to display the preprint in perpetuity.

It is made available under a CC-BY-NC-ND 4.0 International license .

577 43. Wattanakit K et al. Kidney function and risk of peripheral arterial disease: results from the

578 Atherosclerosis Risk in Communities (ARIC) Study. J. Am. Soc. Nephrol. 2007;18(2):629-636.

579 44. Sturgeon KM et al. A population-based study of cardiovascular disease mortality risk in US

580 cancer patients. Eur. Heart J. 2019;40(48):3889-3897.

581 45. Gupta A et al. Association between antecedent statin use and decreased mortality in

582 hospitalized patients with COVID-19. Nat. Commun. 2021;12(1):1325.

583 46. Sinha P et al. Latent class analysis of ARDS subphenotypes: a secondary analysis of the

584 statins for acutely injured lungs from sepsis (SAILS) study. Intensive Care Med.

$585 \quad 2018 ; 44(11): 1859-1869$.

586 47. Schachterle W et al. Sox 17 drives functional engraftment of endothelium converted from

587 non-vascular cells. Nat. Commun. 2017;8:13963.

588 48. Rafii S, Ginsberg M, Scandura J, Butler JM, Ding B-S. Transplantation of endothelial cells to

589 mitigate acute and chronic radiation injury to vital organs. Radiat Res 2016;186(2):196-202.

590 49. ClinicalTrials.gov [Internet]. Bethesda (MD): National Library of Medicine(US). A First-in-

591 Human Study of AV-001 in Healthy Subjects

592 [Internet]2021;https://clinicaltrials.gov/ct2/show/NCT04737486. cited March 24, 2021

593 50. Bethesda (MD): National Library of Medicine(US). A Study of LY3127804 in Participants

594 With COVID-19 (NCT04342897) [Internet]. ClinicalTrials.gov

595 https://clinicaltrials.gov/ct2/show/NCT04342897. cited May 12, 2021

596 51. CDC: COVID data tracker weekly review [Internet]. CDC: COVID data tracker weekly

597 review 2021;https://www.cdc.gov/coronavirus/2019-ncov/covid-data/covidview/index.html.

598 cited April 24, 2021 
medRxiv preprint doi: https://doi.org/10.1101/2021.05.20.21257542; this version posted May 24, 2021. The copyright holder for this preprint (which was not certified by peer review) is the author/funder, who has granted medRxiv a license to display the preprint in perpetuity.

It is made available under a CC-BY-NC-ND 4.0 International license .

52. Al-Aly Z, Xie Y, Bowe B. High-dimensional characterization of post-acute sequalae of

600

COVID-19. Nature [published online ahead of print: April 22, 2021]; doi:10.1038/s41586-021-

601 03553-9

602 53. Schenck EJ et al. Circulating cell death biomarker TRAIL is associated with increased organ 603 dysfunction in sepsis. JCI Insight 2019;4(9). doi:10.1172/jci.insight.127143

604 54. Ma KC et al. Circulating RIPK3 levels are associated with mortality and organ failure during 605 critical illness. JCI Insight 2018;3(13). doi:10.1172/jci.insight.99692

606 55. Sureshbabu A et al. RIPK3 promotes sepsis-induced acute kidney injury via mitochondrial 607 dysfunction. JCI Insight 2018;3(11). doi:10.1172/jci.insight.98411

56. Siempos II et al. RIPK3 mediates pathogenesis of experimental ventilator-induced lung

609 injury. JCI Insight 2018;3(9). doi:10.1172/jci.insight.97102

610 57. Schenck EJ et al. Respiratory Mechanics and Gas Exchange in COVID-19-associated

611 Respiratory Failure. Annals of the American Thoracic Society 2020;17(9):1158-1161.

612 58. Price DR et al. Effect of neutropenic critical illness on development and prognosis of acute

613 respiratory distress syndrome. Am. J. Respir. Crit. Care Med. 2021;203(4):504-508.

614 59. Vincent JL et al. The SOFA (Sepsis-related Organ Failure Assessment) score to describe

615 organ dysfunction/failure. On behalf of the Working Group on Sepsis-Related Problems of the

616 European Society of Intensive Care Medicine. Intensive Care Med. 1996;22(7):707-710.

617 60. ARDS Definition Task Force et al. Acute respiratory distress syndrome: the Berlin

618 Definition. JAMA 2012;307(23):2526-2533.

619 61. Devlin NJ, Brooks R. EQ-5D and the EuroQol Group: Past, Present and Future. Appl. Health

620 Econ. Health Policy 2017;15(2):127-137. 
medRxiv preprint doi: https://doi.org/10.1101/2021.05.20.21257542; this version posted May 24, 2021. The copyright holder for this preprint (which was not certified by peer review) is the author/funder, who has granted medRxiv a license to display the preprint in perpetuity.

It is made available under a CC-BY-NC-ND 4.0 International license .

621 62. Needham DM et al. Core outcome measures for clinical research in acute respiratory failure

622 survivors. an international modified delphi consensus study. Am. J. Respir. Crit. Care Med.

$6232017 ; 196(9): 1122-1130$.

624 63. Varghese F, Bukhari AB, Malhotra R, De A. IHC Profiler: an open source plugin for the

625 quantitative evaluation and automated scoring of immunohistochemistry images of human tissue

626 samples. PLoS One 2014;9(5):e96801.

627 64. Olink. Olink COVID-19 Heat Inactivation Protocol

628 [Internet]https://www.olink.com/content/uploads/2020/04/Heat_Inactivation_Protocol-

629 webv1.pdf. cited April 24, 2021

630 65. Dieterle F, Ross A, Schlotterbeck G, Senn H. Probabilistic quotient normalization as robust

631 method to account for dilution of complex biological mixtures. Application in 1H NMR

632 metabonomics. Anal. Chem. 2006;78(13):4281-4290.

633 66. Do KT et al. Characterization of missing values in untargeted MS-based metabolomics data

634 and evaluation of missing data handling strategies. Metabolomics 2018;14(10):128.

635 67. Benjamini Y, Hochberg Y. Controlling the false discovery rate: A practical and powerful

636 approach to multiple testing. Journal of the Royal Statistical Society: Series B (Methodological)

637 1995;57(1):289-300.

638 

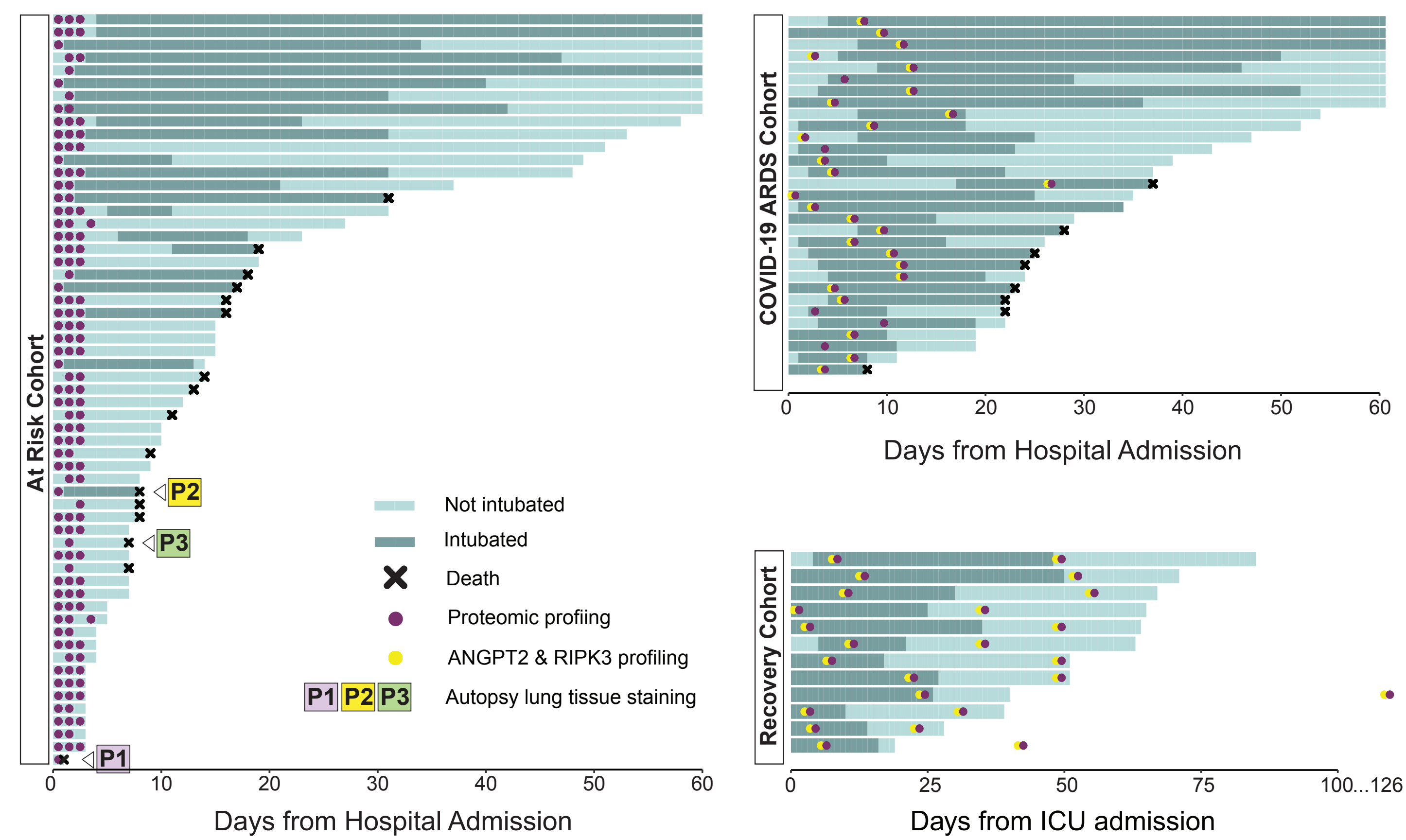

Figure 1: Overview of COVID-19 subjects in the at risk $(\mathrm{N}=59), A R D S(\mathrm{~N}=31)$ and recovery $(\mathrm{N}=12)$ cohorts. Each horizontal line corresponds to one individual. Subjects in the at risk cohort were sampled for proteomics between 1 and 3 times (purple dots). For three of the patients in this cohorts ( $\mathrm{P} 1$, P2, P3) autopsy lung tissue staining was available. Subjects in the ARDS cohort were sampled once, within 10 days of ICU admission. Recovery subjects were sampled twice, once during their ICU stay and once after discharge from the ICU (median 31 days). Patients in the ARDS cohort were additionally profiled for ANGPT2 and RIPK3 (yellow dots) while recovery cohort subjects were profiled for ANGPT2 (yellow dots). 


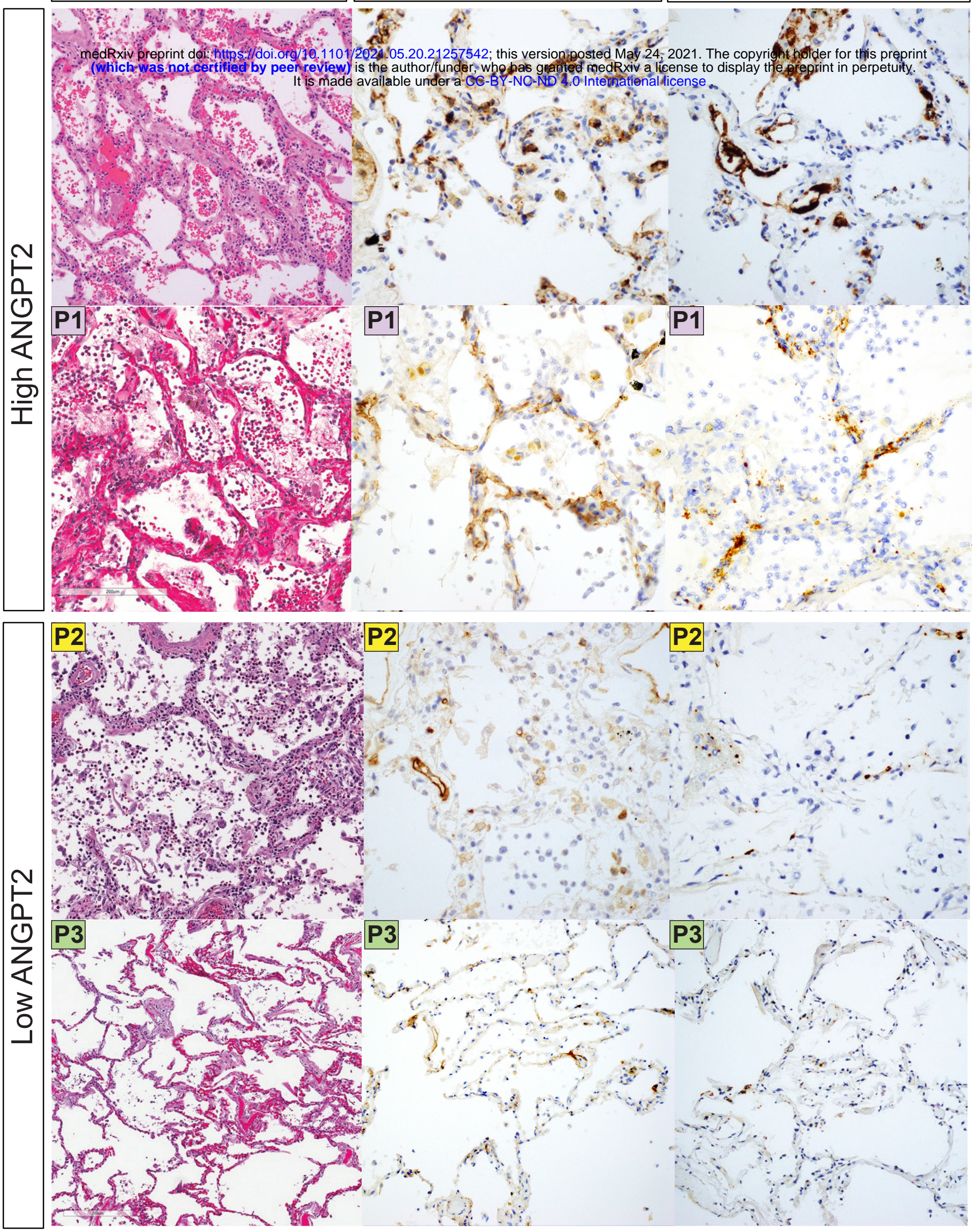

Figure 2: Angiopoietin 2 is associated with CD61 staining microthrombi in COVID-19 ARDS subjects. Angiopoietin-2 (ANGPT2) and CD61 staining in COVID-19 ARDS subjects. Lung autopsy specimens from 20 COVID-19 ARDS subjects were stained for ANGPT2 and CD61. High ANGPT2 (N=10) corresponds to autopsy subjects with ANGPT2 quantification above the median of the autopsy cohort while low ANGPT2 $(\mathrm{N}=10)$ represents the low ANGPT2 cohort. High ANGPT2 was associated with increased CD61 staining $(P=0.005$, Supplementary Figure 1). P1, P2, P3 labels indicate autopsy subjects with serum proteomic data shown in Figure $3 \mathrm{~A}$. 


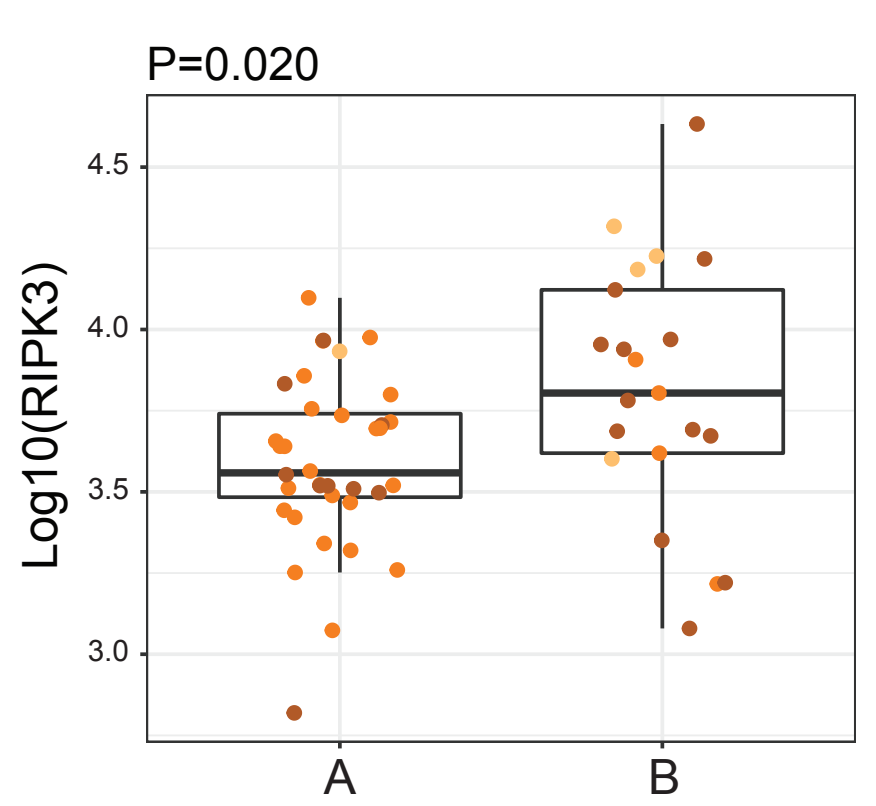

Lower Vascular Higher Vascular Injury

Injury

(B)

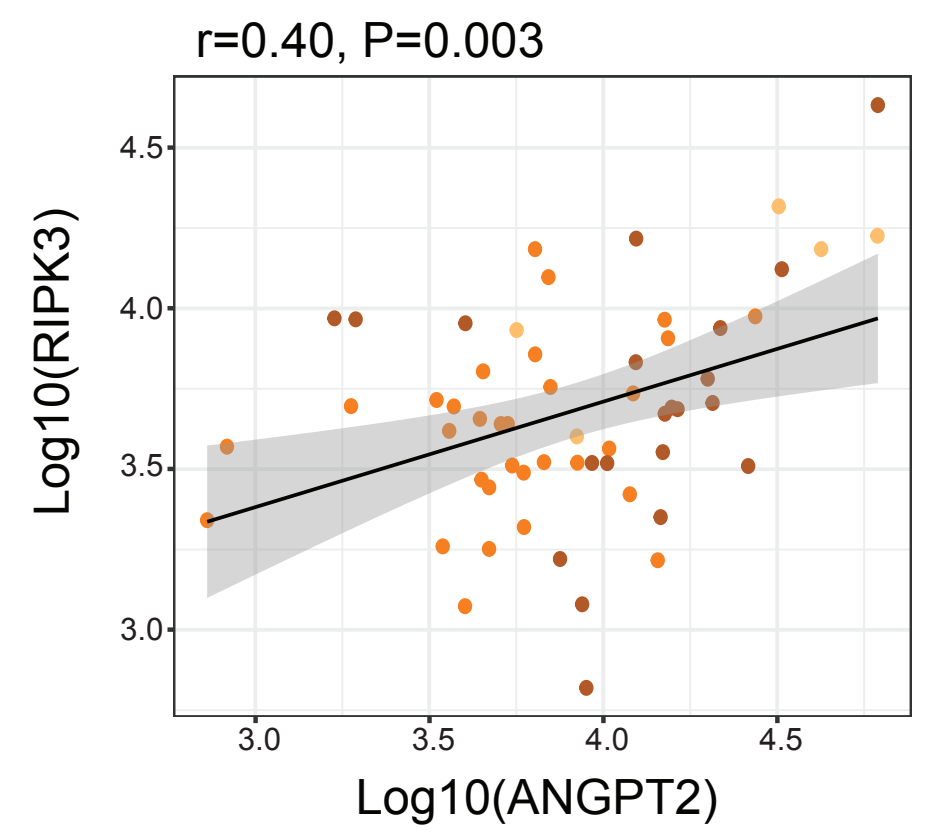

(C)

- COVID-19

- Bacterial sepsis

- Influenza

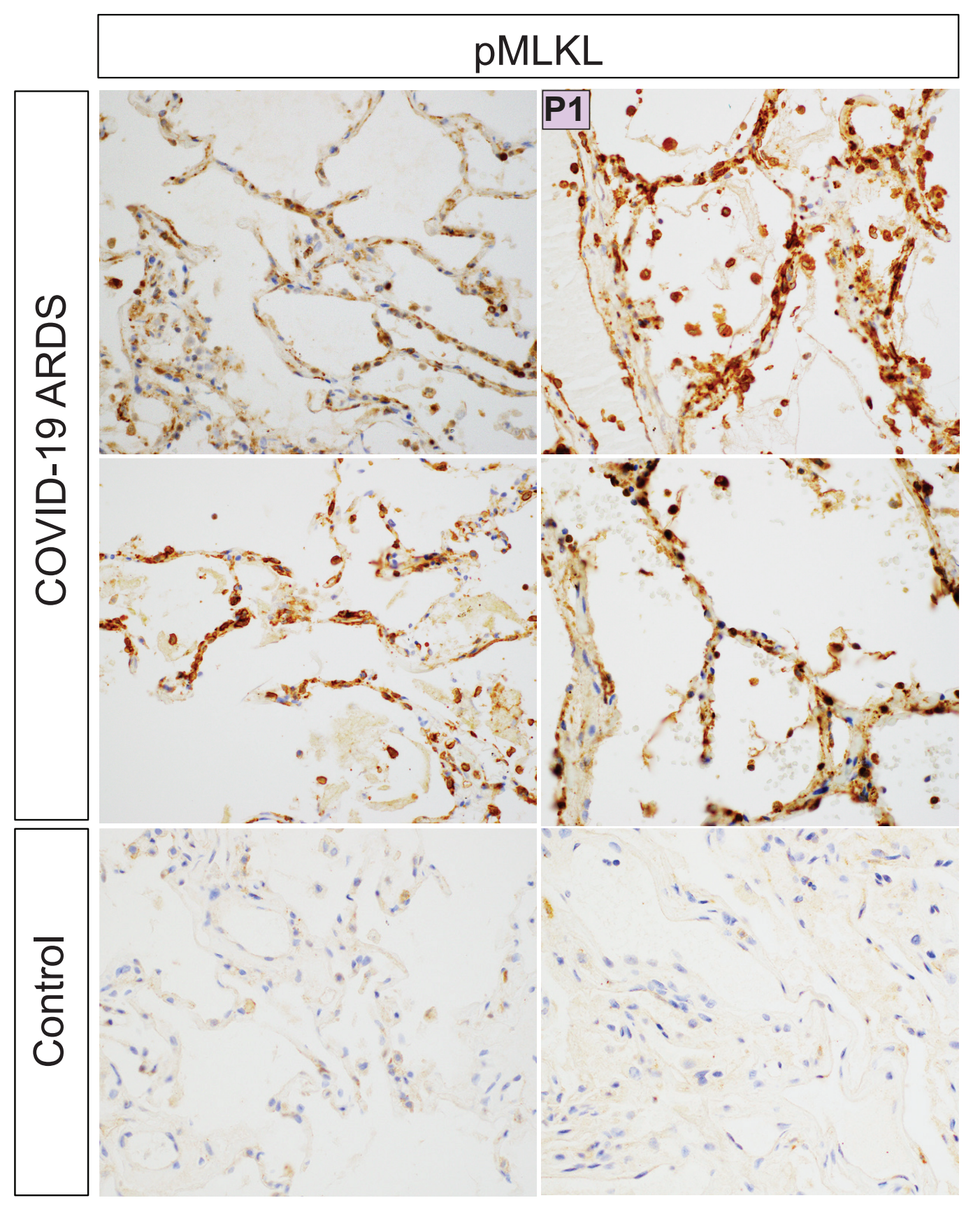

Figure 5: Induction of vascular cell death is associated with ARDS vascular injury. (A) Plasma receptor interacting protein kinase 3 (RIPK3) in ARDS by heatmap cluster (Figure $4 A, N=60$ ). Differential statistic was assessed with a two-sided Mann-Whitney $U$ test. The boxes indicate the interquantile range (IQR) of the data distribution, the line in the box represents the median value and the whiskers extend for 1.5 times the value of the IQR. Dots indicate the protein level in individual patients across the different ARDS categories: COVID-19 (orange), bacterial sepsis (brown) and influenza (mustard). (B) Correlation of plasma RIPK3 and plasma ANGPT2 in the ARDS cohort (Figure 4A, N=60). $r$ indicate the Pearson correlation coefficient of the two variable and P its corresponding $p$-value. The black line represents the linear regression line and the gray area indicates the $95 \%$ confidence interval of the fit. Dots indicate the protein level in individual patients across the different ARDS categories: COVID-19 (orange), bacterial sepsis (brown) and influenza (mustard). (C) Phosphorylated mixed lineage kinase domain-like (pMLKL) staining in COVID-19 ARDS autopsy and healthy control subjects. P1 corresponds to autopsy subject from Figure 2 with high ANGPT2 and high CD61 staining and with serum profiling in Figure 3C showing low circulating vascular proteins. 
medRxilv preprint dol: https://dol.org/10.1101/2021.05.20.21257542; this version posted May 24, 2021. The copyright holder for this preprint (which was not certified by
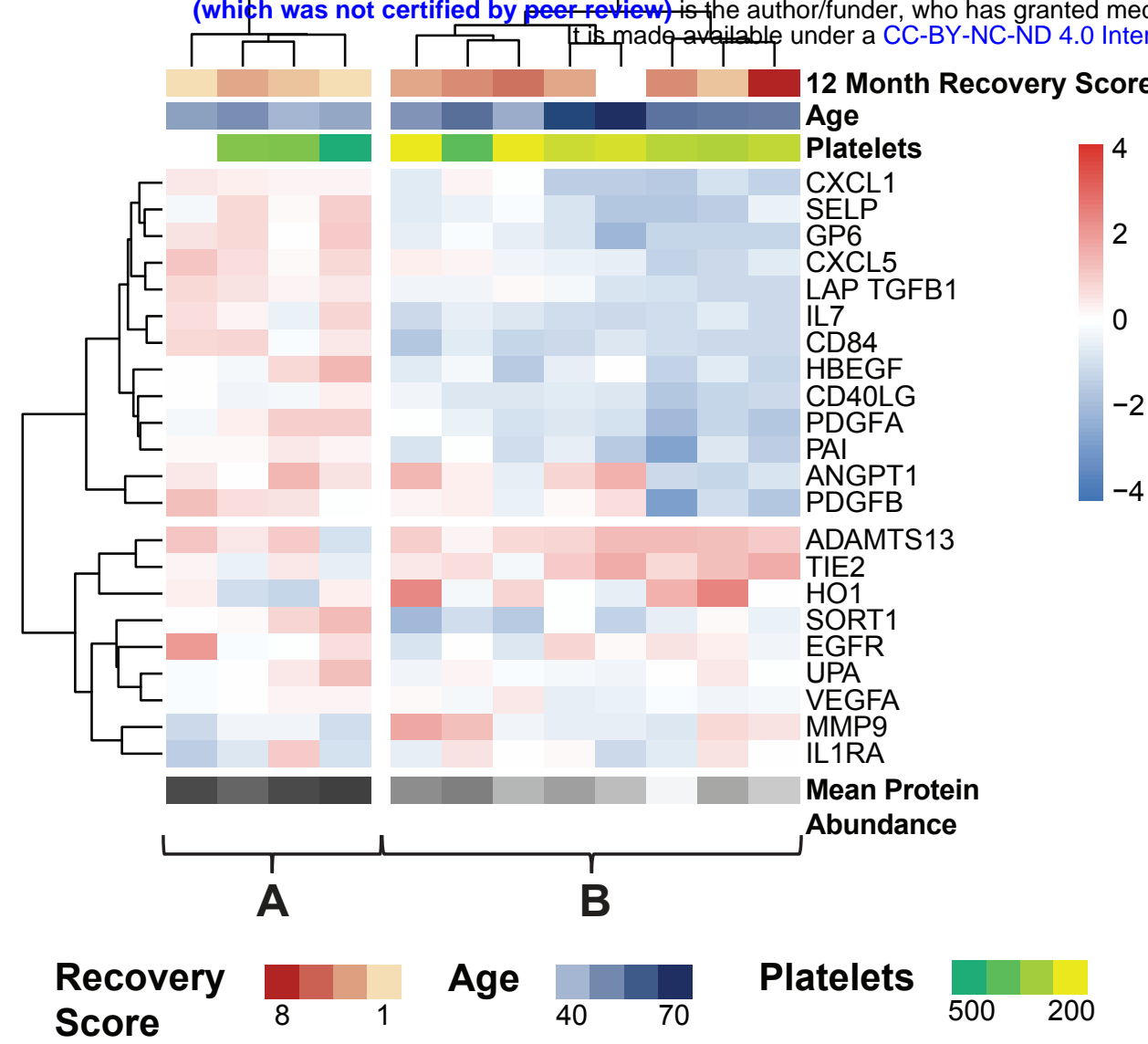

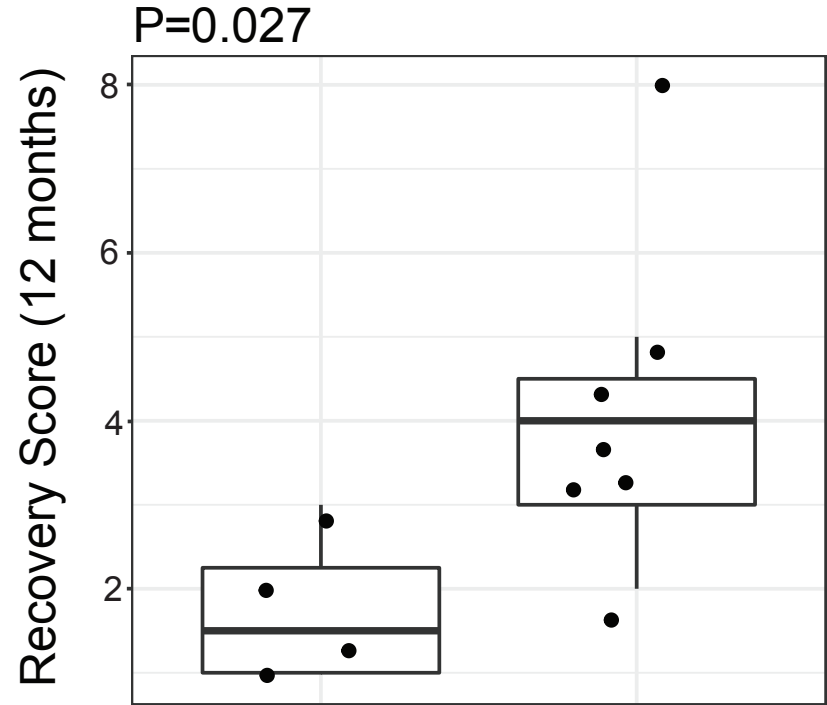

A B

Good Functional Poor Functional

Recovery Recovery

Heatmap Cluster

\section{Mean Protein Abundance high low}

(C)

Angiogenesis

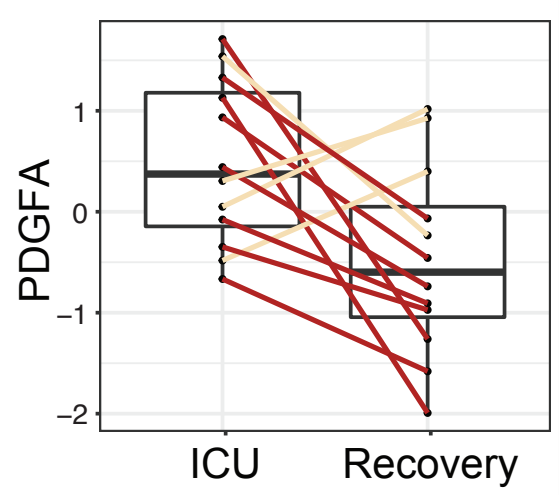

Platelet Degranulation

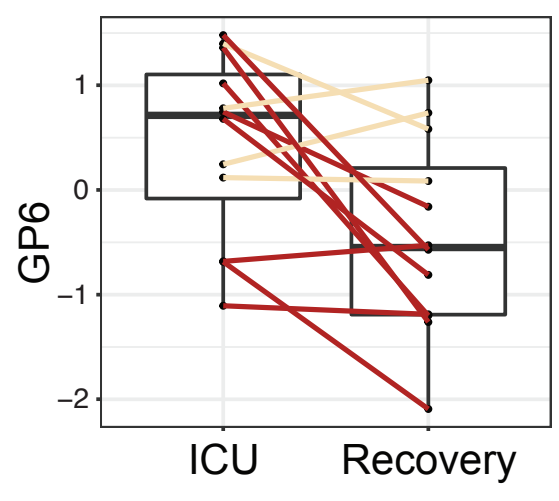

Barrier Intergrity

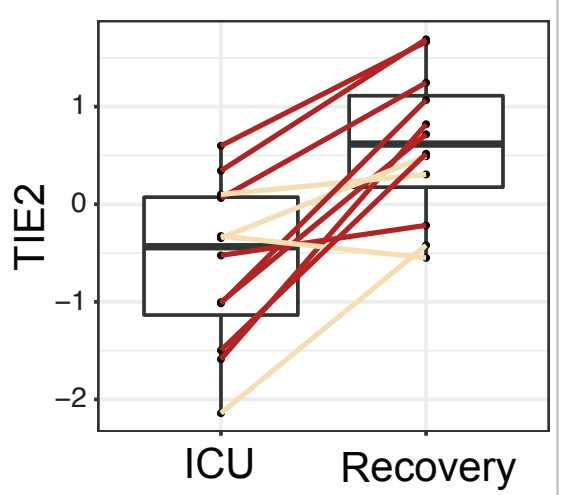

Coagulopathy

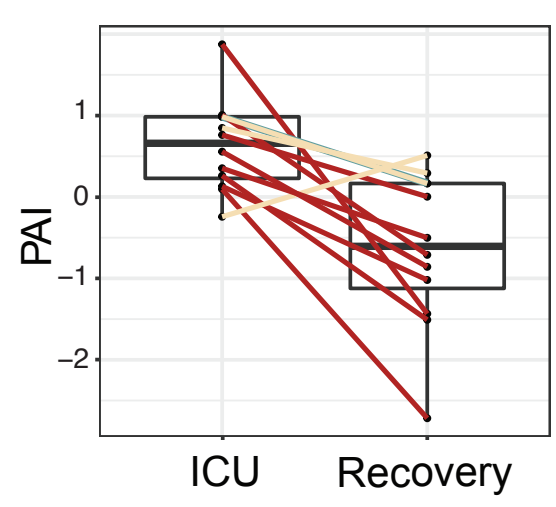

Cluster A (Good Functional Recovery)

Cluster B (Poor Functional Recovery)

Figure 6: Among COVID-19 ARDS recovery subjects $(\mathrm{N}=12)$, longitudinal plasma proteomics identifies a stable protein trajectory associated with good functional recovery. (A) Heatmap of COVID-19 recovery subjects. Functional recovery, age, platelet count and 12 month recovery scores are overlaid at the top. Hierarchical clustering was performed with Ward linkage and Euclidean distance. (B) Follow-up recovery scores at 12 months after ICU admission in the two heatmap clusters. Differential statistic was assessed with a two-sided Mann-Whitney $U$ test. The boxes indicate the interquantile range (IQR) of the data distribution, the line in the box represents the median value and the whiskers extend for 1.5 times the value of the IQR. Dots indicate the protein level in individual patients. High scores indicate worse functional recovery. (C) Trajectory of vascular proteins from ICU to recovery time points by functional recovery group. The boxes indicate the interquantile range (IQR) of the data distribution, the line in the box represents the median value and the whiskers extend for 1.5 times the value of the IQR. Dots indicate the protein level in individual patients in the two timepoints. Values from the same patient are linked by a line and colored according to the corresponding heatmap cluster: A (cream) or B (red). Differential statistic of the protein trajectories between the two patient clusters was computed with a linear model. All displayed trajectory differences were significant to an adjusted $p$-value $<0.25$. 